Frederik Van Dam

\title{
LIBERAL FORMALISMS
}

Frederik Van Dam is a postdoctoral research fellow at the University of Leuven (KU Leuven) and the Flemish Research Foundation (FWO). His work is situated at the intersection of Victorian literature and nineteenth-century intellectual history. He is the author of Anthony Trollope's Late Style: Victorian Liberalism and Literary Form (2016) and one of the editors of the Edinburgh Companion to Anthony Trollope (forthcoming); his most recent project is a literary history of nineteenth-century diplomatic practice, with a particular focus on British and Irish views on the Risorgimento. He also has an interest in word and image studies and has created a film about J. Hillis Miller, The Pleasure of that Obstinacy. Postal address: Department of Literary Studies, Faculty of Arts, KU Leuven, 3000 Leuven, Belgium. E-mail: frederik.vandam@kuleuven.be.

The recent efflorescence of scholarship on Victorian liberalism was facilitated by the return of formalism as a methodological paradigm. The 'new' formalism is characterised by a focus on the literary adaptation of Enlightenment concepts and practices, which critics have analysed in two distinct ways: one movement seeks to explore literature's potential to foster certain modes of attention, whereas the other aims to reinvigorate the critique of ideology with a formalist impetus. This bifurcation can also be detected in current work on Victorian liberalism. In various ways, certain scholars have shown that Victorian writers reassessed the idea of the aesthetic in an attempt to modify and renew the idea of self-reflexive reason, while others have unpacked the relation between the development of literary forms and their expression of lived experience. I suggest that this body of work could be enriched by an acknowledgement of the importance of the literary text's articulation of propositional knowledge. A formalism that would allow this aspect to be paraphrased could reveal theories that complement Victorian liberalism, such as civic republicanism. Just as formalism is intertwined with the practice of paraphrasing, indeed, so is the relationship between Victorian liberalism and civic republicanism mutually constitutive rather than exclusive. I conclude these theoretical reflections with a short reading of a passage from Anthony Trollope's Phineas Finn. 
Keywords: new formalism, Victorian studies, liberalism, civic republicanism, paraphrasis, Anthony Trollope

Since the turn of the century, liberalism has become a privileged concept in the study of Anglophone literature, from the early modern period (e.g. Mohamed, 2011) to the present day (e.g. Foley, 2009). Restricting my scope to the literature of the second half of the nineteenth century, I would suggest that the interaction between the study of Victorian politics and the study of Victorian aesthetics has created a chain reaction, revealing aspects of both that would otherwise not come to light. In what follows, I first give a brief overview of what in my view has been the catalyst in this reaction, the new formalism, before analysing its effects on the field of Victorian studies. In general, new formalists seek to foster a renewed appreciation of the ways in which works of literature are enmeshed in concepts and practices that first flowered during the Enlightenment: scholars in this movement have shown how the emergence of certain literary forms can be tied to a desire to articulate ideals such as critique or autonomy. This central contention has been developed in two ways: whereas certain critics have used it to show how works of literature exceed the constraints of their immediate context, for others it has served as an incentive to untangle the complex web of interactions between literary texts and the politics they subtend, without lapsing into a hermeneutics of suspicion. The kind of liberalism that Victorianists have recovered in recent years, I argue, has been determined by which kind of new formalism they practise: certain Victorianists have tried to reassert the aesthetic aspects of works of Victorian literature so as to uncover their self-critical agency, while others have tunnelled their way through these texts' surface in order to reveal their complex relation to lived experience. Even though this productive interchange has yielded major new critical insights, it is not without its blind spots. What has been relatively absent in the surge of interest in Victorian liberalism, I believe, is a concern with the subtle movement of ideas at the level of the word. As Simon Jarvis puts it, the danger with the 'formula politics of style, as usually wielded', is that it 'empties both the terms it glues together. It diminishes politics to its least complex moment, that of wearing a badge' (Jarvis, 2010: 932). While this charge can hardly be levelled at the sophisticated treatment that critics have recently lavished on Victorian liberalism, it does remind us that a veritably historical inquiry into literature should incorporate the study of repertoire, 'the quasi system of local expressive forces that individual prosodic gestures may take on or develop' (934). In this vein, I illustrate what an attention to the processes with which literary texts create meaning could add to current debates about Victorian liberalism. 


\section{New formalism}

Although one must bear in mind that the new formalism can be 'better described as a movement than a theory or method' (Levinson, 2007: 558), it is possible to make a division between two types of related practices. As Marjorie Levinson has argued, one can see the new formalism as either as a backlash against or as a continuation of the new historicism and associated forms of ideological critique.

The first kind of new formalism takes an approach that 'assigns to the aesthetic normsetting work that is cognitive and affective and therefore also cultural-political' (Levinson, 2007: 559). 'Normative' critics are 'campaign[ing] to bring back a sharp demarcation between history and art, discourse and literature' (Levinson, 2007: 559). The subtlest spokesperson of this formalism is arguably Charles Altieri, who finds inspiration in the New Criticism as it was originally conceived, but not without certain reservations. Following one of the basic findings of poststructuralism, Altieri feels that New Criticism strayed from the path when it forged a critical vocabulary that privileged the constative dimension of language over its performative potential. However, Altieri does not believe that the realisation of this distinction should clear the road for the introduction of context. Rather, it should lead us back to the original impetus behind the New Criticism, its goal of developing a definition of the literature that is organised around 'conative' rather than cognitive values: 'extended experience of the lyric develops powers and modes of attention' that transcend 'the ability to represent our own interests to ourselves, to understand the psychology involved in much the same way that we understand the interrelations of molecules' (Altieri, 2001: 260, 260-261). Since this ability exceeds a straightforward understanding rationalism, Altieri's formalism is at bottom a reassessment of Enlightenment ideas about knowledge and judgement. This turn to epistemology is, as we will see, a crucial element in recent work on Victorian liberalism.

The second kind of new formalism, which Susan Wolfson has dubbed 'activist' (2000: 1), wants 'to restore to today's reductive reinscription of historical reading its original focus on form' (Levinson, 2007: 559). Scholars in this line of thinking want to infuse their examination of historico-political discourses with an attention to the aesthetic means through which these are mediated. This practice is in many ways an attempt to return the new historicism to its formalist premises. Initially, as Richard Strier points out, the new historicism took its cue from Erich Auerbach and Leo Spitzer, for whom 'formal features of a text, matters of style, can be indices to large intellectual and cultural matters' (Strier 2002: 213). 
Whereas Auerbach and Spitzer were interested in those stylistic elements that are motivated by the text as a whole, however, new historicists turned their gaze to small passages that interrupt the work's supposedly organic unity and that thus identify 'the larger, extra-literary systems or wholes that suggest why or under what conditions the work came into being in the first place' (Levinson, 2007: 566). Unfortunately, the innovative nature of this procedure has often given way to the principles of the old historicism, with critics treating passages 'almost entirely in terms of content' (Strier, 2002: 213).

Countering this tendency, Strier defends a historicism that would pay attention to actual, “"lived" experience' as expressed in style and syntax, against 'the machinery of "archaeology" and archive-churning' (2002: 212-13). In the footnote that accompanies this claim, Strier singles out Michel Foucault's The Archaeology of Knowledge and The Order of Things, but, importantly, not the later volumes of The History of Sexuality or Foucault's lectures at the Collège de France on the hermeneutics of the subject, in which Foucault develops the idea that human subjects can regain agency by conceiving of their lives as works of art. There is a certain degree of overlap between the 'aesthetics of existence' that Foucault puts forward in these works and Strier's attention to 'lived experience'. As we will see, the later Foucault is also an important presence in work on Victorian liberalism.

Given the once widespread assumption that the socially committed nature of Victorian literature renders it unreceptive to formalist analysis, it is not surprising to find that the new formalism has been spearheaded by work in other areas, namely early modern literature (Dubrow, 1990) and Romanticism (Wolfson, 2000). It may therefore seem tempting to conclude that the proposals of Altieri and Strier have not found resonance in the criticism of Victorian literature. Nevertheless, there have been a number of studies that explicitly partake of the return to form. Two major interventions in the theorisation of the new formalism have been made by critics with a Victorianist background, Isobel Armstrong (2000) and Jonathan Loesberg (2005). In the narrower field of literary criticism of Victorian literature itself, Loesberg has launched a call for a healthy, 'freeing' dose of formalism to supplement the historicist, cultural and Foucauldian methodology that has traditionally dominated Victorian studies (1999: 544). In a different and more expansive way, Caroline Levine has argued that Victorianists should examine the collision of social with literary forms to see what nonintentional political effects they produce. Her concept of form thus takes on many different guises: 
If forms can be defined as ways of imposing order, of shaping and structuring experience, the cultural critic can attend to conflicts and overlaps not just among race, class, and gender but also among forms of knowledge, forms of narrative, forms of subjectivity, forms of space, forms of circulation, forms of community, forms of worship, forms of administration, forms of intimacy, and forms of thought. (2006: 635)

Even in studies that do not present themselves as responding to these calls, such as Nicholas Dames's The Physiology of the Novel (2007), an increasing sensitivity to the necessity of talking about literary works in terms of their form can be perceived. It is in work on Victorian liberalism, however, that the imprint of the new formalism on Victorian studies has been the deepest.

\section{Victorian liberalism}

Liberalism, it bears reminding, is not a uniform construct, but a multifaceted constellation of doctrines, bearing on such broadly historical topics as the rise of capitalism, the rule of law, the idea of freedom and the gradual emergence of a social democratic ideal. In Britain, its roots can be traced to the tumults of the seventeenth century, which in many ways gave voice to the desire to assert religious and political liberties of more modern formulations (Skinner, 1998). Anticipating Enlightenment philosophers such as John Locke, Jean-Jacques Rousseau and Immanuel Kant, thinkers such as Thomas Hobbes and James Harrington conceived of the individual as 'the proprietor of his own person or capacities, owing nothing to society for them' (Macpherson, 1962: 3). Limiting the task of government to 'protect[ing] owners against illegitimate incursion upon their property and to maintain[ing] conditions of orderly exchange' (Carens, 1993: 2), this theory aided the rise of commercial society, in which property means power, as well as of civil society, in which political decisions are reached through dialogue, language and debate. In political history as well as in literary studies, Victorian liberalism has often been portrayed as failing to honour the promise of a fullyfledged democratic system, however, while letting the development of capitalism go unchecked.

On the one hand, intellectual and political historians have often identified Victorian liberalism with the promotion of orthodoxies such as free trade, laissez-faire and anti-statism. This image of liberalism is tied to the birth of the Liberal party in the 1840s, when the Whigs 
made political capital out of Robert Peel's reform of the Corn Laws and joined forces with Radicals and various dissenting voices. In their response (or the absence thereof) to the Irish Famine, which had prompted Peel's reform, this motley crew held on to these orthodoxies in an attempt to transform Ireland into a capitalist society - an attempt that failed and caused Victorian liberals to rethink their principles. ${ }^{1}$ On the other hand, many Victorianists have long preferred to take a genealogical, Foucauldian approach, in which liberalism is regarded with suspicion because it in fact denies the citizen agency: like the inmate subjected to the disciplinary power of the Panopticon, the citizen 'must never know whether he is being looked at at any one moment; but he must be sure that he may always be so' (Foucault, 1977: 201). It is this narrow view of liberalism, based on Foucault's early work, in which the possibility of agency is exposed as an illusion, that led previous scholars such as D. A. Miller (1988) to interpret the Victorian novel as an embodiment of disciplinary discourse.

Although this sketch inevitably distorts the subtle attention that Victorian liberalism has received over the years, it highlights how the ground has shifted since the turn of the century. Energised by the potential proffered by the newfound respect for formalism, critics have challenged the picture of Victorian liberalism yielded by the combination of historicism with Foucault's genealogical framework. One group of critics has proceeded by reassessing the legacy of Enlightenment rationalism within Victorian liberalism. Without a doubt, the most influential voice in this debate has been Amanda Anderson, who has tried to capture the Victorian articulation of the liberal ideals of agency and critique through an analysis of detachment and cosmopolitanism in literary texts (2001). As she puts it in her 2005 manifesto, the Victorians had a project of 'autonomous self-authorisation' that hovers between Enlightenment rationalism and post-Victorian aestheticism (2005: 197). Anderson thus hopes to give the Victorians their due by writing them into a dialectical stage in the narrative of modernity, which she defines as 'an ongoing achievement of consciousness with intimate effects on character and on ethical life' (2005: 200). Although this statement may seem to repeat an older call for a turn to ethics, I believe that it is in fact spurred by the interest in Enlightenment concepts and practices of critique that are part and parcel of the normative version of new formalism.

This affiliation is even stronger in the work of David Wayne Thomas, who interprets the Victorian conceptualisation of liberal agency as an aesthetic concept that cannot be wholly reduced to ideological categories such as race, gender or class. Nor does he posit that the Victorians theorised agency as an unqualified belief in subject-centred originality associated with the Enlightenment. Thomas conceives of liberal agency as the ability to consider a 
situation from the perspective of its participants before acting on this consideration. Liberal agency thus denotes 'many-sidedness' (2004: 3-48). His project's difference from older forms of formalism is clear in his ambition 'to reassert aesthetic values without resorting to a neoconservative nostalgia for a dubiously conceived golden era of appreciation' (2004: ix). Thomas nevertheless qualifies the feasibility of this project, suggesting that 'aesthetics cannot be reclaimed along such lines until we reassess the character of modern liberal culture as well' (2004: ix). In his discussion of Walter Pater's aesthetics, he fleshes out this claim by using Altieri's expressivist theory of subjective agency:

'Expression' ... indicates, in such an account as Altieri's, not the representation of some truth that lay previously within the agential interior. Instead, expression names the bringing into being of something legible but also potentially new - new even to the agent. ... This view makes sense of an intentionality that does not draw on naively essentialising claims about interiority or deep subjectivity. And this prospect bears on, among many other things, what we might take the word style to mean.

(2004: 45; Thomas's emphasis)

The cultivation of liberal agency, in this methodology, is thus as much a matter of selfconsciousness as it is a matter of allowing oneself to be surprised.

Even though it would be foolhardy to attempt to generalise their approaches, there are significant overlaps between Anderson's and Thomas's work on the conative. Other critics, including Jonathan Loesberg, add even more colours to this palette. From a Nietzschean point of view, Regenia Gagnier has maintained that literature can represent forms of volition that are at odds with liberal agency (2010). Resentment is one such alternative, 'a form of agency that misguides and misjudges, blocking and frustrating desires' (2009: 244). This concept is embodied by the protagonist of Anthony Trollope's novel The Prime Minister (1876), a novel in which resentment 'affectively recuperates the world that [Trollope's] politics rationally repudiate' (2009: 243). Gagnier's attention to the imbrication of affect with cognition reveals that in Trollope's novels there is a disturbing hollowness to subjective experience. To illustrate the very different results that this conative methodology can lead to, one might contrast Gagnier's ideas with those of Daniel Malachuk, who accuses 'the hoary modern culture of scepticism' of having obscured the moral objectivism of the Victorians (2005: 153). According to Malachuk, the Victorians believed that moral objectivity could only be realised 
through a perfectionist notion of the state. Victorian state theory is not a matter of authoritarianism versus libertarianism, of Arnold versus Mill, but a 'continuation of the perfectionism of the Enlightenment' (2005: 175n). Even if Malachuk's polemical stance sets him apart from the sceptical work of Gagnier, both can be said to practise a normative formalism inasmuch as, like Anderson and Thomas, they see the formal aesthetic of Victorian literature as an expression and adaptation of the idea of self-reflexive reason that emerged during the Enlightenment.

Other critics have taken a more historicizing approach in their reassessment of Victorian liberalism. Like the new formalist as conceived by Strier, Lauren M. E. Goodlad, for instance, has analysed Victorian works of fiction in the terms of their aesthetics of existence.

Suggesting that Foucault's later texts on governmentality are better suited to probing the paradoxes of governance in Victorian culture than his earlier genealogical framework, Goodlad has shown how certain Victorian novels are characterised by a worldview in which

[f]reedom and power agonistically provoke each other, each representing the precondition of the other's possibility. To be free is not - as in crude liberal thought - to escape to some autonomous realm outside of power, but, rather, to exercise one's own power to influence and be influenced by others.' (2003: 14)

The works of Victorian authors articulate this different kind of freedom by negotiating between two different forms of character - between, on the one hand, the prescriptive character of the self-helping individual, which implies 'the limitless improvability of all human beings', regardless of race, class or gender (119); and, on the other hand, the descriptive character of the born-and-bred gentleman, which implies 'a comparatively limited view of individual improvement and, thus, a naturalisation of relatively fixed socio-political hierarchies' (25). The formal impetus behind Goodlad's historicising approach has intensified in her more recent work on the forms of Victorian realism. ${ }^{2}$ Developing in response to imperial encounters, she argues, the realist novel helped shape a geopolitical aesthetic: it was part of an attempt to breach 'the cognitive disjunction between localised metropolitan experience and the global conditions that underlie it' (2010a: 405).

Strier's plea to pay attention to literary forms as the embodiment of lived experience is also echoed in the work of Elaine Hadley, albeit in a very different way. Pace the normativists, Hadley argues that liberal agency was not only 'a form of cognition' but also 'a social practice' that 'only summoned its coherence and cogency at times of crisis' (2005: 98, 
99, 98). Matthew Arnold may very well have called upon his countrymen to become their best selves in Culture and Anarchy, but we should not forget that it was the Hyde Park riots that prompted that call. As such, Victorian liberalism is often no more than 'an aversive response to social alterity’ (2005: 98). Elaborating this premise in Living Liberalism Hadley specifies that mid-Victorian liberalism 'contributes forms of abstracted embodiment to the long tradition of liberalism' (2010: 48). Her aim is to show not just how Victorian liberalism formalises reason in a private site of cognition, but also how cognitive forms are given a material manifestation through, among others, the introduction of the secret ballot, the turn to signature journalism, the reform of Irish Land Laws in the wake of mismanagement of the Irish Famine and the structure of the realist novel: 'Novels seek not surprisingly to educe the liberal individual through their formal operations, such as third-person omniscient narration, when, for instance, other sites of contestations - the newspapers, the hustings - do not' (Hadley 2010: 82). With the flexibility of form as its crux, Hadley's argument reminds one of Caroline Levine's strategic formalism. Pre-empting criticism that this makes 'form' a catchall term for concepts that should be epistemologically kept distinct, Hadley points out that the

term form and its variants punctuate the discourse of mid-Victorian liberalism, as we see with James Fitzjames Stephen, whose liberal citizens are ‘formed' by liberal education. Form and reform are central conceptual categories during this period that do and undo a good deal of theoretical labour, that become the focus of foundational debates within liberalism, and that writers therefore continually use and abuse.

(2010: 49; Hadley's emphasis)

Even though Goodlad and Hadley differ clearly in their conclusions, from a methodological point of view they are part of a cohort of critics who have used the language of formalism to shed light on the contradictions of lived experience in a liberal society. Provocatively, Nathan Hensley maintains that the logic of liberalism is in essence the same as that of 'the most basic form of human interchangeability: slavery' (2009: 607). Reading J. S. Mill's Logic (1843) against Wilkie Collins's Armadale (1866), Hensley argues that both slavery and liberalism overlap in their attempt to transform the particular human into a universal subject. Irene Tucker, too, calls attention to the interplay between the general and the particular, but does so by elaborating the difference between the state's universalism and the nation's historicism $(2000,2003)$. Other critics have similarly argued that the liberal 
project is both made possible and compromised by its conflicted relation to class (Robbins, 2007), imperialism (Mehta, 1999), radicalism (McWilliam, 2005) and cultural property (Bailkin, 2005; see also 2004). Showing how history has seeped into the form of literary texts and united in their opposition to the genealogical framework that dominated Victorian studies up until the turn of the century, these critics practise what appears to be an activist formalism.

As this admittedly dense analysis of current scholarship shows, Marjorie Levinson's distinction between a normative and an activist camp in the new formalism can be mapped with some degree of precision onto recent work on Victorian liberalism. Although there are numerous subtle differences in tone and emphasis in these scholars' work, broad brushstrokes can be detected: whereas the normativists, for want of a better word, focus on the way in which Victorian literary texts 'enact' certain models of agency by opening themselves up to the reader's criticism, the activists focus on how the formal features of the literary texts encode a tension between liberal principles and their manifestations in real life. These two types of analyses are not necessarily mutually exclusive: the aestheticising formalism of normative critics can reveal how the Victorians cultivated liberal subjectivity, while the historicising formalism of activist critics can be used to nuance how this kind of subjectivity was actually experienced. Vice versa, this body of work also sheds more light on the political predilections behind the new formalism. The way in which the new formalism has manifested itself in Victorian studies suggests that it has itself been driven by a particular, self-aware commitment to liberalism. Amanda Anderson mentions, for instance, that to uncover the liberal nature of Victorian culture, critics must turn the tables on 'cultural studies, New Historicism, postcolonialism and queer theory' and give 'primacy to political philosophy or political theory as a disciplinary partner' $(2005: 196)$. While this statement may seem to have reactionary overtones, as if the achievements of these various contextualising approaches have expired, it must in fact be read as a call to safeguard them. It seems to me that Anderson is issuing a call for a criticism that pays attention to the condition of possibility for forms of scholarship that are more explicitly concerned with identity politics. Without attention to the way in which texts 'form' subjectivities, any claim for the emancipatory potential that the study of literature can afford is void. New formalists, in this view, are in fact attempting to legitimise and consolidate the work of the more culturally attuned critics in whose footsteps they are treading.

\section{The politics of paraphrasis}


Once one realises that recent scholarship on Victorian liberalism is actually a manifestation of the return to formalism, it becomes clear that this approach may have certain limits. In this body of work, indeed, one encounters the typically formalist penchant for abstraction: to focus on the ways in which literary forms produce certain kinds of subjectivity is to obscure the ways in which others kinds of subjectivity are produced on the level of the semantic. What would be the impact on the revaluation of Victorian liberalism, then, if one were to at the same time read these works with an attention to the dispersal of meaning across the page? Can our understanding of Victorian liberalism be further refined if we also pay attention to the thinking process within a given passage? Although these questions are motivated by the current interest in surface reading, which has developed alongside the new formalism (Best and Marcus, 2009), I would like to think them through by returning to the model of the paraphrase; in contrast to formalism, this older methodology is concerned with the ways in which language makes sense. Whereas formalism is concerned with gauging the depth of a text's underlying structure, the paraphrase is concerned with 'the syntactical process of discovering what it might be thinking' (Longenbach, 2004: 73-74; as quoted in Leighton, 2007: 172).

Cleanth Brooks famously condemned the paraphrase as a heresy because as such it supposedly violates the literary work's intent to 'return to us the unity of the experience itself as man knows it in his own experience' (1947: 212-13). Certain critics have recently revoked this verdict, however, arguing that formalism and the paraphrase are mutually constitutive. If formalism allows one to determine the rules that govern a literary text as a whole, the paraphrase allows one to trace and describe the vagaries of meaning at a more local level - the level of the word. Angela Leighton, who is nothing if not a committed formalist (2007), has suggested that literary critics would do well to also listen to how a literary work 'sounds': 'If meaning, in poetry, is dispersed across the differentials of its phrasing in time, then surely paraphrase becomes not only possible, but in fact in the very nature of reading' (2009: 172). Simon Jarvis's call for a science of prosody has much in common with Leighton's endeavour. Reflections such as theirs are not limited to the study of the lyric. Discussing the formalist analysis of prose texts, Patrick Fessenbecker similarly 'defend[s] reading "with", as opposed to reading "against", the "grain" of the text, and to do so in a way that does not dismiss formal considerations, but instead recognises their contribution to a text's paraphrasable content' (2013: 134). As an example of what a paraphrastic criticism can contribute to the formalist study of liberal ideals in Victorian literature, let me conclude by reading a short sample of the thinking process in the work of Anthony Trollope. 
Anthony Trollope, who famously claimed that he was 'an advanced, but still a conservative Liberal' (1999: 251), occupies a privileged place in recent work on Victorian liberalism. Amanda Anderson, for instance, has argued that Trollope's portrayal of liberal subjectivity is characterised by a tension between 'traditional individual virtue (it quintessentially defines the "gentleman") and a kind of impersonal truth-telling or critique that is aligned both with the evaluative diagnoses of the narrative and with specific challenges by characters within the story to the doxa that defines the embedded communities that Trollope seems often to affirm' (2007: 512). From the historicising perspective of the activists, Lauren Goodlad has maintained that Trollope's early Barchester novels exemplify what she describes as descriptive character formation (cf. supra). The formalist incentive fuelling examinations of Trollope's liberalism is clearest in Lynette Felber's account (2010). She maintains that Trollope found an expressive equivalent for his moderate progressivism in the aesthetic form of the sequence novel or roman fleuve, which allows the author to stretch out the development of character over a larger canvas. These revisionist efforts thus correct D. A. Miller's influential Foucauldian claim that the tolerant narration and providential scheme which Trollope uses in Barchester Towers in fact encourage the reader to embrace disciplinary institutions (1988: 111). Salutary as they are, these conclusions imply that the emancipatory potential of Trollope's thinking is to be found in his artistic practice more than in his actual, explicit engagement with liberal theories. An attention to the literal dimension of Trollope's engagement with liberalism is illuminating, however, as the following paraphrase of a short passage from Phineas Finn (1869) illustrates.

Phineas Finn is a political Bildungsroman that charts a young Irishman's career in Parliament. In the middle of the novel, Phineas Finn's political mentor, the radical Mr Monk, sends him a letter in which he tackles the subject of the day, the necessity of Reform (a hot issue for a novel written while the Second Reform Bill was in Parliament). Falling back on several rhetorical topoi, Monk proceeds to contrast his liberalism with that of two 'great authorities' who are left unnamed. The first authority proclaims that political representation should be based on finding the best men. According to Mr Monk, however, 'only one excellence may be acknowledged, and that is the excellence of likeness' (Trollope, 1989: 293). Mr Monk thus pictures a metaphoric relation between a representer and a represented: it is a relationship of likeness, substitution, governed by the "'necessary link" of a resemblance' (de Man, 1979: 66), which leads to an ideal of mimesis. Not content with this avowal, $\mathrm{Mr}$ Monk also illustrates his theory with a simile: 'as a portrait should be like the person portrayed, so should a representative House be like the people whom it represents' (293-94). 
Falling back on the image of the painting, Mr Monk neatly reinforces his theory with his language. This, however, does not suffice: Mr. Monk also disagrees with a second great authority, who holds that the 'House of Commons should be the mirror of the people' (294). No, says Mr Monk, 'not its mirror, but its miniature' (294). Miniature is here used in a specific sense: 'the artist must be careful to put in every line of the expression of that evermoving face' (294). Mr Monk thus seems to adjust his earlier claim, positing that the relation between the people and its representatives is structured along the lines not of metaphorical likeness, but along the lines of personification or prosopopeia, which etymologically means the conferring of a face (Lukács, 1971: 33-34). It is the artist's duty, Mr. Monk holds, to give a voice to a nation otherwise left voiceless. It will be clear that there is some friction between Monk's two images: whereas the portrait implies static substitution, the miniature rests on a dynamic contiguity. This friction only increases as Mr. Monk goes on: "not only is the picture imperfect, - a thing of snatches, - but with years it becomes less and still less like its original' (294). Mr Monk's use of personification thus ultimately implies that 'the original face can be missing or nonexistent' (de Man 1981: 30). One is reminded here, in a very different register, of Deleuze and Guattari's proposition that '[c]ertain assemblages of power (pouvoir) require the production of a face, others do not' (2004: 195). What has started out as a defence of the liberal ideal of a representational politics thus gradually morphs into a critique of this ideal. By means of rhetorical topoi, Trollope presents the reader with the movement from one conception of liberalism to another, thus guiding the reader from a default position to one that is more nuanced and complex.

This movement has conceptual underpinnings that can be traced, I would suggest, to Trollope's growing interest in civic republicanism. By civic republicanism, I am referring to a tradition of political thinking that emphasises participation in public life and the positive freedom to develop citizen character. Extending back to Plato, Aristotle, and the 'Machiavellian moment' of Renaissance Florence, the early-modern legacy of civic republicanism had allegedly disappeared by the beginning of the nineteenth century with the ‘ideological triumph’ of classical liberalism (e.g. Skinner, 1998: x), with its emphasis on negative liberty, warranting freedom from interference. This view, however, rests on the assumption that liberalism and civic republicanism are incommensurable, and ignores the late-Victorian turn toward collectivism, germinal in John Stuart Mill's drift toward cooperative socialism and articulated more fully in Thomas Hill Green's Hegelian idealism. This concern with the common good as opposed to the individual's liberty can also be found in the poetry of Robert Browning, Elizabeth Barrett Browning, Arthur Hugh Clough and A. 
C. Swinburne. While it may be apparent that this theory would give Trollope ammunition for a critique of classical liberalism, it may be less apparent how the passage I have paraphrased above puts it to work. Some of this fogginess can be cleared when we consider the intellectual sources with which Trollope is engaging.

The two great authorities that Mr Monk refers to are most likely Matthew Arnold and Walter Bagehot, whose Culture and Anarchy and The English Constitution dealt with the Second Reform Bill in critical and cynical terms, respectively. Mr Monk's own thoughts, however, stretch back much further: scholars have not noticed that in using the image of the portrait Trollope is harking back, quite literally, to the second paragraph of book five of Cicero's De Re Publica. Trollope - or Trollope's character - is thus effectively using the words of an ancient writer to criticise his contemporaries. This explains why we may read into Mr Monk's words a civic republican critique: in his articles on and biography of Cicero, Trollope lauds Cicero for, precisely, his civic republicanism (Van Dam, 2016: 68-73). Trollope's Life of Cicero demonstrates that the Roman statesman was always working in the interest of the common good and not out of self-interest. There may seem to be a certain irony in the fact that Trollope puts his words in the mouth of a radical, however. Cicero, after all, played a fairly negative role in the discourse of Victorian liberalism: he was often regarded with contempt by positivist radicals such as Richard Congreve, Frederic Harrison and Edward Spencer for his opposition to Caesar's despotic democratism. Other radicals, however, recognised that Cicero offered a source of inspiration for civic republicanism. For John Stuart Mill, an ardent admirer, the negative conception of liberty, warranting freedom from interference, was incomplete without the positive freedom to participate in public life: 'The maximum of the invigorating effect of freedom upon the character', Mill wrote in Considerations on Representative Government (1861), is only obtained when the person acted on either is, or is looking forward to becoming, a citizen as fully privileged as any other' (2008: 254). ${ }^{3}$ As in Mill's notion of an elevated, public-spirited utilitarian ethos, Trollope's Life advocates concern for the welfare of others. Liberty, for instance, was 'very dear to' Cicero, 'dear to him not only as enjoying it himself, but as a privilege for the enjoyment of others' (Trollope, 1880: 1.81-82). Understood as an allusion to Mill's belief that civic republicanism could be a corrective to liberalism, then, Mr Monk's invocation of Cicero's simile is certainly apposite.

Although a reading of the intellectual subtext of one short passage in one particular novel admittedly does not count as hard evidence, I hope it illustrates how a paraphrase of the ideas that lie on the surface of the literary text can illuminate and complement the concepts 
encoded in its form. By following the thinking process in a given passage, and listening to the movement and rhythm of its ideas, a paraphrase can illustrate the complexity of the kind of propositional claims that a literary text makes, as opposed to the non-propositional knowledge that formalists aim to uncover. In other words, by using topoi to construct an argument, a literary text demonstrates itself to be fuelled by a kind of agency that may or may not coincide with the agency it cultivates through the enactment of conative practices or through the simulation of lived experience. To be sure, this is not a call for a radically new way of reading. As Leighton and Fessenbecker indicate, and as most literary scholars realise, paraphrasis as a reading strategy did not disappear with the arrival of the New Criticism, but has remained part and parcel of our critical apparatus. It has, however, been condemned to some sort of half-life, in which it is suffered to operate but only in disguise. A formalism that would more openly embrace the value of the paraphrase, as I have defined it here, has much to gain, however. A paraphrastic formalism can open up new avenues and help us reach a better or, at least, fuller understanding of the ways in which literary texts instantiate an engagement with political developments such as, for instance, the synergy between liberalism and civic republicanism in the literature of the nineteenth century. This might, in turn, give the new formalism a more communitarian appeal.

\section{Notes}

1 Subject to change over place and time, Victorian liberalism in fact had a much more complex identity and encompassed a much wider range of ideas than its beginnings would suggest, as historians such as Jonathan Parry have illustrated (1993, 2006).

2 See also the cluster of essays on the topic of Trollopian form edited by Goodlad for Literature Compass (2010b), which includes essays on Trollope's geopolitical aesthetic, the issue of seriality, and the nature of the chapter.

3 For analyses of Mill's civic republicanism, see Biagini (1996) and D. E. Miller (2000).

\section{References}

Altieri, Charles (2001). 'Taking Lyrics Literally: Teaching Poetry in a Prose Culture'. New Literary History 32.2: 259-81.

Anderson, Amanda (2001). The Powers of Distance: Cosmopolitanism and the Cultivation of Detachment. Princeton: Princeton UP. 
Anderson, Amanda (2005). 'Victorian Studies and the Two Modernities'. Victorian Studies 47.2: 195-203.

Anderson, Amanda (2007). ‘Trollope's Modernity’. ELH 74.3: 509-34.

Armstrong, Isobel (2000). The Radical Aesthetic. Malden, MA: Blackwell Publishers.

Bailkin, Jordanna (2004). The Culture of Property: The Crisis of Liberalism in Modern Britain. Chicago: Chicago UP.

Bailkin, Jordanna (2005). 'The Place of Liberalism'. Victorian Studies 48.1: 83-91.

Best, Stephen and Marcus, Sharon (2009). 'Surface Reading: An Introduction'.

Representations: 108.1: 1-21.

Biagini, Eugenio F. (1996), 'Liberalism and Direct Democracy: J. S. Mill and the Model of Ancient Athens'. Citizenship and Community: Liberals, Radicals and Collective Identites in the British Isles, 1865-1931. Ed. Eugenio F. Biagini. Cambridge: Cambridge UP. 21-44.

Brooks, Cleanth (1947). The Well Wrought Urn: Studies in the Structure of Poetry. New York: Reynal \& Hitchcock.

Carens, Joseph H. (1993). 'Possessive Individualism and Democratic Theory: Macpherson's Legacy'. Democracy and Possessive Individualism. Ed. Joseph H. Carens. New York: SUNY Press. 1-18.

Dames, Nicholas (2007). The Physiology of the Novel: Reading, Neural Science, and the Form of Victorian Fiction. Oxford: Oxford UP.

de Man, Paul (1979). 'Reading (Proust)'. Allegories of Reading: Figural Language in Rousseau, Nietzsche, Rilke and Proust. New Haven: Yale UP. 57-78.

de Man, Paul (1981). 'Hypogram and Inscription: Michael Riffaterre's Poetics of Reading'. Diacritics 11.4: 17-35.

Deleuze, Gilles and Guattari, Félix (2004). A Thousand Plateaus. Trans. Brian Massumi. New York: Continuum.

Dubrow, Heather (1990). A Happier Eden: The Politics of Marriage in the Stuart Epithalamium. Ithaca, NY: Cornell UP.

Felber, Lynette (2010). 'The Advanced Conservative Liberal: Victorian Liberalism and the Aesthetics of Anthony Trollope's Palliser Novels'. Modern Philology 107.3: 355-71.

Fessenbecker, Patrick (2013). 'In Defense of Paraphrase'. New Literary History 44.1: 117-39. Foley, Andrew (2009). The Imagination of Freedom: Critical Texts and Times in Contemporary Liberalism. Johannesburg: Witwatersrand UP. 
Foucault, Michel (1977). Discipline and Punish: The Birth of the Prison. Trans. Alan Sheridan. New York: Vintage.

Gagnier, Regenia (2009). 'Gender, Liberalism, and Resentment'. The Politics of Gender in Anthony Trollope's Novels: New Readings for the Twenty-First Century. Eds Margaret Markwick, Deborah Denenholz Morse and Regenia Gagnier. Aldershot: Ashgate. 23548.

Gagnier, Regenia (2010). Individualism, Decadence and Globalization: On the Relationship of Part to Whole, 1859-1920. Basingstoke: Palgrave Macmillan.

Goodlad, Lauren M. E. (2003). Victorian Literature and the Victorian State: Character and Governance in a Liberal Society. Baltimore: Johns Hopkins UP.

Goodlad, Lauren M. E. (2010a). 'Cosmopolitanism's Actually Existing Beyond; toward a Victorian Geopolitical Aesthetic'. Victorian Literature and Culture 38.2: 399-411.

Goodlad, Lauren M. E., ed. (2010b). Trollopian Form. Literature Compass 7.9 (2010): 85175.

Hadley, Elaine (2005). 'On a Darkling Plain: Victorian Liberalism and the Fantasy of Agency'. Victorian Studies 48.1: 92-102.

Hadley, Elaine (2010). Living Liberalism: Practical Citizenship in Victorian Britain. Chicago: U of Chicago P.

Hensley, Nathan K. (2009). 'Armadale and the Logic of Liberalism'. Victorian Studies 51.4: 607-32.

Jarvis, Simon (2010). 'For a Poetics of Verse'. PMLA 125.4: 931-35.

Leighton, Angela (2007). On Form: Poetry, Aestheticism, and the Legacy of a Word. Oxford: Oxford UP.

Leighton, Angela (2009). 'About About: On Poetry and Paraphrase'. Midwest Studies in Philosophy 23: 167-76.

Levine, Caroline (2006). 'Strategic Formalism: Toward a New Method in Cultural Studies'. Victorian Studies 48.4: 625-57.

Levinson, Marjorie (2007). 'What Is New Formalism?'. PMLA 122.2: 558-69.

Loesberg, Jonathan (1999). 'Cultural Studies, Victorian Studies, and Formalism'. Victorian Literature and Culture 27.2: 537-544.

Loesberg, Jonathan (2005). A Return to Aesthetics: Autonomy, Indifference, and Postmodernism. Stanford: Stanford UP.

Longenbach, James (2004). The Resistance to Poetry. Chicago and London: Chicago UP. 
Lukács, Georg (1971). The Theory of the Novel: A Historico-Philosophical Essay on the Forms of Great Epic Literature. Trans. Anna Bostock. Cambridge, MA: MIT Press.

Malachuk, Daniel S. (2005). Perfection, the State, and Victorian Liberalism. Basingstoke and New York: Palgrave Macmillan.

Macpherson, C. B. (1962). The Political Theory of Possessive Individualism: Hobbes to Locke. Oxford: Clarendon.

McWilliam, Rohan (2005). 'Liberalism Lite?'. Victorian Studies 48.1: 103-11.

Mehta, Uday Singh (1999). Liberalism and Empire: A Study in Nineteenth-Century British Liberal Thought. Chicago: U of Chicago P.

Mill, John Stuart (2008). 'Considerations on Representative Government.' On Liberty and Other Essays. Ed John Gray. Oxford: Oxford UP.

Miller, D. A. (1988). The Novel and the Police. Berkeley: U of California P.

Miller, Dale E. (2000). ‘John Stuart Mill's Civic Liberalism'. History of Political Thought 21.1: 88-113.

Mohamed, Feisal (2011). Milton and the Post-Secular Present: Ethics, Politics, Terrorism. Palo Alto: Stanford UP.

Parry, Jonathan (1993). The Rise and Fall of Liberal Government in Victorian Britain. New Haven: Yale UP.

Parry, Jonathan (2006). The Politics of Patriotism: English Liberalism, National Identity and Europe, 1830-1886. Cambridge: Cambridge UP.

Robbins, Bruce (2007). Upward Mobility and the Common Good: Toward a Literary History of the Welfare State. Princeton and Oxford: Princeton UP.

Skinner, Quentin (1998). Liberty before Liberalism. Oxford: Oxford UP.

Strier, Richard (2002). 'How Formalism Became a Dirty Word, and Why We Can't Do without It'. Renaissance Literature and Its Formal Engagements. Ed Mark David Rasmussen. New York: Palgrave. 201-15.

Thomas, David Wayne (2004). Cultivating Victorians: Liberal Culture and the Aesthetic. Philadelphia: U of Pennsylvania P.

Trollope, Anthony (1880). The Life of Cicero. London: Chapman and Hall.

Trollope, Anthony (1989). Phineas Finn: The Irish Member. Ed David Skilton. London: The Trollope Society.

Trollope, Anthony (1999). An Autobiography. Eds Michael Sadleir and Frederick Page. Oxford: Oxford UP. 
Tucker, Irene (2000). A Probable State: The Novel, the Contract, and the Jews. Chicago: U of Chicago P.

Tucker, Irene (2003). 'International Whiggery'. Victorian Studies 45.4: 687-97.

Van Dam, Frederik (2016). Anthony Trollope's Late Style. Edinburgh: Edinburgh UP.

Wolfson, Susan J. (2000). 'Reading for Form'. Modern Language Quarterly 61.1: 1-16. 